\title{
Legal Protection and Fulfillment of the Outsourcing Workers Rights after the Enactment of Law Number 11 Year 2020 Concerning Job
}

\author{
Okky Ocktavianti $^{1, *}$, Maria Adisti Anggia Cahyani ${ }^{2}$, Arinto Nugroho ${ }^{3}$
}

${ }^{1,2,3}$ Universitas Negeri Surabaya

*Corresponding author. Email: okky.19049@mhs.unesa.ac.id

\begin{abstract}
Outsourcing workers' definitions have changed following the enactment of Law Number 11 the Year 2020 concerning Job Creation. Regulations which related to outsourcing workers were previously regulated in articles 64-66 of Law Number 13 Year 2003 concerning Manpower that holds outsourcing laborers only involve in supporting work activities while in Government Regulation No. 35/2021 as the latest regulation and a derivative rule of the Job Creation Law, it is not explained in detail of the characters and the work type classification. In business processes, many companies employ outsourcing workers because the company considers being more focused on mandatory activities by giving the operational issues to the third party so that the company could be more focused on the company's main business. However, the workers are still doing the work directly related to the production process instead of supporting activities as regulated by law. In this paper, the authors discuss two fundamental problems, firstly, how the legal protection for outsourcing workers could be manifested following the enactment of the job creation law. Secondly, how to guarantee the outsourcing workers' rights are fulfilled in the workplace. This research is categorized into normative legal research that analyzes legal norms.
\end{abstract}

Keywords: Outsourcing workers, Legal protection, Type of work boundaries

\section{INTRODUCTION}

The country's role in labor as a function of making regulations and supervising workers regulations in Indonesia is in line with the theory of a welfare state proposed by Prof. Mr. R. Kranenburg stated that a state must actively realize welfare and treat it fairly which can be felt equal and balanced by the entire community instead of for certain groups of people [1]. Regarding this topic, Jurgen Habermas also states that the welfare assurance of the community is the major thing for a modern state. Furthermore, according to Habermas, the welfare certainty of all the individuals is realized in the form of, the threat of unemployment, accident, illness, old age, and death of the breadwinner protection have to be covered largely through the welfare provisions of the state [2]. This theoretical idea has been delivered in the preamble of the 1945 Constitution of the Republic of Indonesia that stated the state of Indonesia which shall protect all the persons in Indonesia and all the independence and the land that has been struggled for, and to improve the public welfare level, to educate the life of the native people and to participate toward the establishment of a world order based on freedom, perpetual peace, and social justice [3]. Thus, employment regulation which regulates the professional relationship between employers and employees is in line with the goals of the state, so that welfare can be realized. Workers as a side who are full of limitations should get legal protection as the fulfillment of their constitutional rights [4].

The population growth of working-age people in Indonesia is not balanced with the availability of jobs that can provide permanent work, therefore, an unfixed term employment system appears or known as outsourcing work as a form of contract that occurs when a company did the commercial contract with another company to provide certain services within a certain period. The practice of outsourcing at this time is increased by both entrepreneurs and outsourcing service providers themselves. Along with the development of employment related to the outsourcing system, there are many negative things for the development of workers or laborers [5]. Many workers' rights are ignored by companies that use outsourcing services. In the labor world, relationships between workers and employers should have a mutually beneficial, harmonious, and balanced relationship, consequently, it does not cause 'the wrong man in the wrong place' which creates an imbalance in the environment for workers [3].

One of the government regulations that regulate outsourcing service is Law Number 13/2003 concerning Manpower affairs (Today referred to as the Manpower Law) which is contained in articles 64th to 66th. Limitatively, the Manpower affairs Law stated the types 
of work that can be transferred to the other company with a work contract agreement which be required to meet the following requirements: 1 ). The type of certain work is conducted separately from the main occupation, in this case, laborers from an outsourcing company should not be obligated to do the main job or tasks directly related to the core production process, except for supporting service tasks or project that are not directly related to the production process and 2). Done by direct or indirect command from the director. However, in 2020 a new law has been issued, it is Law Number 11/2020 concerning Job Creation (Today referred to as the Job Creation Law) to create job opportunities [6]. Along with the enactment of the Manpower law causes the articles 64th to 65th of the Manpower affairs Law were substituted with Article 81 points 18 and 19 of the Job Creation Law, thus, outsourcing topics is only regulated in Article 81st point 20 of the Job Creation Law which substituted Article 66th Manpower Law [7].

In addition, the regulation related to outsourcing can be found in Government Regulation No. 35 /2021 as a derivative regulation of the Job Creation Law which does not explain the classification between the supporting work and core work for outsourced workers. In business processes, many companies employ outsourcing workers because the company considers being more focused on mandatory activities by giving the operational issues to the third party, so, that the company could be more focused on the company's main business, however, the workers are still doing the work which related to the core operation instead of supporting job as regulated by manpower law [8]. The unregulated topic of work category limitation in the manpower law will have an impact on legal protection and assurance of the outsourced workers' rights fulfillment, hence, the authors discuss about the perspective of law valid protection for outsourcing employees following the ratification of the job creation law and how to guarantee the outsourcing workers' rights are fulfilled in Indonesia.

\section{METHODS}

The type of research used by the authors in this study is a type of juridical-normative research. The research approach in this study is a statutory and concept approach. The juridical- normative research method is research in which the objects are statutory regulations and library materials. In this research, we analyze the juridical review of the new regulations of outsourcing workers in Indonesia.

\section{RESULTS AND DISCUSSION}

\subsection{Outsourcing System Arrangement in Indonesia}

There are two types of work in Indonesian law, permanent work and temporary work. The advantages possessed by workers with fixed-term jobs are more than workers with non- permanent jobs, one of the advantages is the guarantees for continuity of work and pension benefits after retirement. Meanwhile, workers with nonpermanent jobs are often known as outsourcing whose positions are certainly weaker than workers with permanent jobs. Before further discussion, it is necessary to know in advance the meaning of the word "outsourcing", as stated by Maurice F Greaver II outsourcing is defined as "strategic use of outside parties to perform activities. Traditionally handled by internal staff and resources". This definition describes outsourcing as a behaviour of transmitting a portion of the company's operation and decision-making rights to another affiliation (outside provider), whereas this action is firm in a cooperation contract. There is also a viewpoint that states outsourcing process is the delegation of day-by-day tasks and management of a business operation to an outside alliance (outsourcing service supplier company) [3].

Article 64th in the Manpower law is the main subject of discussion in this study which states that contract work agreements can be categorized into two groups, firstly, the transition of a job by an outsourcing company to another company is conducted at a service provider workplace. The worker's elements that can be done are two things, the first is focused on the products in material perspective, while the second is focused on individuals in the term of services [4]. Afterward, the work contract agreement (outsourcing) in Article 65th of the Manpower law is one type of commit part of the operation implementation to another party, in the process of work contract being started according to Article 65th of the Manpower law, it must be obeyed as stated in the agreement [9]. the Manpower law in article 66th point 1, stated that employees from an outsourcing business should not be utilized to execute the main occupations or tasks directly linked to the production activity, except for supporting service jobs or procedures that are not directly related to the production process. In article 6th point (1)c the decree of ministry of manpower and transmigration republic of Indonesia number 220/men/x/2004 explains that supporting activities are activities that can support and provide assist execution in work which synergy with the company's workflow. However, in the article there is no clear limitation between the main activities and supporting services in the employer company which will lead to multiple interpretations.

After the ratification and promulgation of the Job Creation Law, some changes have been occurred to numerous existing laws in Indonesia, one of them was Law Number 13/2003 concerning Manpower, there were several articles were deleted and added with several provisions, for the outsourcing related regulation, there were changes including the removing of Articles 64th and 65th of the Manpower law also Articles 81st points 18 and 19 of the Job Creation Law, so that currently "outsourcing" is only regulated in Article 81st point 20 of the Job Creation Law which substitutes Article 66th of the Manpower Law. Article 81st point 20 of the Job Creation Law has changed the arrangements of Article 
66th of the Manpower Law, there were several adjustments, such as, the removal of provisions respecting the types of job that perhaps transferred to outsourcing supplier [10], there is an additional associated to the protection in the event of a change in outsourcing corporations, as well as additional regulations linked to licensing for the outsourcing company. Regarding to the Minister of Manpower there are also several regulations governing outsourcing, including the law product of the Minister of Manpower and Transmigration Number 19 the Year 2012 concerning Requirements for Assigning of Partial Job Implementation to Other Company surrogated by Regulation of the Minister of Manpower Number 27 the Year 2014 respecting Regulation of the Minister of Manpower and Transmigration Amendment Number 19 the Year 2012 concerning Requirements for Assigning of Partial Work Implementation to Other Company, and amended for the second time by Regulation of the Minister of Manpower Number 19 the Year 2019 concerning the second amendment to the Regulation of the Minister of Manpower and Transmigration Number 19 the Year 2012 regarding Requirements for Assigning of Partial Work Implementation to Other Company.

However, with the existence of the transitional rules for the Job Creation law, all regulations, like manpower law, ministerial regulations, and government regulations before the Job Creation law are no longer valid [11]. Then the implementing rules of the Job Creation law that regulate outsourcing work are Regulation of Indonesian Government Number 35 the Year 2021 concerning Work Agreements for Certain Time, Outsourcing, Working Time and Rest Time, and Termination of Employment. In the Government Regulation, outsourcing is regulated in Chapter III and there are only 3 articles, there are article 18th, article 19th, and also article 20th. Article 18th which regulates work agreements for outsourced workers, namely PKWT or PKWTT, is stated in point (1). Furthermore, it requires the agreement in written form as stated in point (2). Then point (3) regarding the protection of outsourced workers corresponding to incomes, welfare, working conditions, and disputes that be possible take place are implemented after the provisions of regulations and become the control of the Outsourcing corporation. Then point

(4) requires the implementation of point (3) to be included in the job contract, Company Regulations, or Collective Employment Contract. Meanwhile, Article 19th point (1) requires the shift of defence of rights for employees in the term of an adjustment in the Outsourcing business and since the 'work-oriented' object still remains. The demand for the handover the protection of rights is a guarantee for the continuity of work for the peasant which employment association is based on the PKWT in the Outsourcing Company, this is regulated in point (2). Then, if the worker does not receive a guarantee for the continuity of work as referred to in point (2), the Outsourcing Company is responsible for fulfilling the rights of the laborer. The last article is
Article 20 point (1) whereas the Outsourcing Company must take the form of a legal entity and must fulfill the business license issued by the Central Government. Furthermore, the requirements and procedures for obtaining a business license are conducted following the provisions of the legislation regarding procedures, norms, standards, and criteria for corporation licensing set by the Central Government, this provision is regulated in point (2). From Government Regulation No. 35/2021 mentioned above, article 18th and article 19th are important to discuss because these 2 articles contain law protection for outsourced employees following the ratification of the job creation law.

\subsection{Legal Protection and Fulfillment of The Rights Of Outsourced Workers After The Enactment Of Law Number 11 Year 2020 Concerning Job Creation}

Legal protection is always related to the role and function of the law as a regulator and protection of the interests of society. Bronislaw Malinowski in his book "Crime and Custom in Savage", says that the law does not only play a role in situations full of violence and conflict but that the law also plays a role in daily activities [5]. Law protection for outsourced laborer is very necessary considering their position as workers is usually in a lower or weaker level. Protection of workers is planned to guarantee the fulfillment of the essential rights of employees and ensure equal opportunity and nondiscriminatory action to generate welfare for laborer.

The abolition of provisions related to the core operation and non-core business process boundary, then, the Job Creation law has made the labor market more flexible by giving employers the freedom to use contracted or outsourced workers who can be recruited with low wages and terminated easily. Furthermore, another result is a stable condition in the number of permanent workers, with long-term job contracts. In contrast, outsourced workers tend to earn lower wages and have fewer workers' rights, making it quite interesting for employers. Moreover, if employers use outsourced workers for all types of work, Indonesia's employment morals will be threatened because the goal of enactment of the job creation law is to eliminate the boundaries between main operation and non-essential business procedure, especially the rights of laborer as stated in the 1945 Constitution of the Republic of Indonesia. Corresponded to legal protection and human rights for workers, this has been regulated and secured by the constitution in Article 27th point (2) of the 1945 Constitution of the Republic of Indonesia as the fundamental of the Indonesian state constitution which states "Every citizen shall have the right to work and to earn a humane livelihood." In the reformation era, the concept of human rights is firmly regulated in the 1945 Constitution in the Second Amendment in Article 28 D point (2) which reads "Every person shall have the right to work and to receive fair and proper remuneration and treatment in employment.". In consequence, it can be 
concluded that the right to work is one of the human rights that must be respected in its implementation. The study relation problem in this paper is about the absence of boundaries between the core business which is usually implemented by employees of the company and for noncore business by outsourcing workers, it makes a threat to the human rights of outsourcing workers and the effect is felt directly by both the fixed-term contract or the outsourced workers. The flexibility or convenience provided by the Government to entrepreneurs eradicates the moral value and human rights of workers, especially to obtain eligibility as guaranteed in the constitution in this case, such as work continuity, old age remuneration or pensions, severance pay, and monthly allowances or bonuses. The welfare of outsourcing workers is not the responsibility of the companies that use their services, this makes entrepreneurs take the shortcut and cheap way by using outsourcing services for all work in their business, both core business and non-core business. That way, the company will save money, compared if they recruit its employees and become their responsibility, especially in paying pension, severance pay, bonuses, and allowances every month. The degradation of labor regulations in Indonesia has resulted in workers' rights disappearing from the previous condition like the assurance of receiving monthly allowance at work as permanent employees, currently, a job guarantee is only a slogan but not with guaranteed benefits, bonuses, pensions, and severance pay like permanent employees in general companies have. In this job creation law, especially related to Outsourcing Workers, it seems that the context tends to be more profitable for the employers and the rights of workers as regulated in the constitution are slowly being forgotten. This is also contrary to article 23rd point (2) of the Universal Declaration of Human Rights (UDHR) which declares "everyone without any discrimination, has the right to equal pay for equal work" and the article 7th of the International Covenant on Economic, Social, and Cultural Rights. (ICESCR) mentions that employees have the right to equal remuneration for work or equal remuneration for services performed for work without any distinction.

The legal protections that exist in the Job Creation Law Number 11 the Year 2020 and Government Regulation Number 35 the Year 2021 is the principle of Transfer of Undertaking Protection of Employment or TUPE, contained in point (3.18) of the legal considerations of the Decision of the Constitutional Court Case Number 27/PUU-IX/2011 express that "by applying the principle of transfer of protection, when the employer company no longer provides wholesale jobs or the provision of worker/labor services to an old outsourcing company, and assigns the work to a new outsourcing company, as long as the work ordered still exists and continues, the new service provider company must continue the existing employment contract, without changing the terms of the contract, without the consent of the parties concerned, except for changes something to increase benefits for workers/laborers due to gaining experience and years of work".
Regarding the clause on guaranteeing the continuity of the employment relationship, it has actually been ever regulated in Article 4 point 3, in decree of the ministry of manpower and transmigration Republic of Indonesia Number Kep- 101/MEN/VI/2004 respecting Licensing Procedures for worker Service Provider Companies (specifically for the contract of employee services), which is in that Article, requires an "affirmation that (a) company providing labor services is willing to accept workers/laborers from outsourced companies services who previously work for the outsourced company for a long period in the event of a replacement company providing services for labor workers".

This means that workers/laborers who work as outsourced "employees" at a user's company are still guaranteed the continuity of their working relationship, even though they always change their "flag" or workplace. Likewise, with the obligation to provide an experience letter, hence, the wages of the worker/laborer are no longer required to meet the minimum wage standard but must be adjusted to the period of service and competence.

The existing protection attempt in the Job Creation Law and its implementing regulations regarding the work continuity of outsourced workers only include scope on the transfer of "flags" or workplace when the outsourcing company moves the workers' rights as long as the work remains still. Meanwhile, the same assurance for work continuity as permanent employees recruited by the company itself for core business does not yet exist, despite under the amendments to Article 66th of the Job Creation Law which does not contain work limitations between core business and non-core business, that causes companies are allowed to hand over all work in their business to outsourcing workers, thus, the guarantee of work continuity which owned by permanent employees who usually do core business will be lost because all employees can be replaced with outsourced workers. Therefore, huge efforts are needed to avoid a more detrimental effect on Indonesian workers. The rights enforcement for workers to continue working and the eligibility to receive work benefits must be pursued again, consequently, employers do not arbitrarily use outsourced workers and impose all responsibility for employee welfare on outsourced companies.

\section{CONCLUSION}

The regulation related to the outsourcing system in Indonesia is contained in Law Number 13 the Year 2003 concerning Manpower, which is stated in Articles 64th to 66th. The manpower law provides provisions regarding boundaries on the fields of work that are allowed to use the outsourcing system but following the enactment of Law Number 11 the Year 2020 concerning Job Creation Law, there were changes regarding outsourcing in Indonesia, where Article 64th and Article 65th of the Manpower Law were removed and there were changes to Article 66th which was replaced with Article 81st point 
(20) of the Job Creation Law. Some adjustments in the provisions of Article 66th of the Manpower Law which are replaced by Article 81 st point 20 include the removal of boundaries regarding the fields of work that are allowed to use the outsourcing system. Legal protection exists when the application of the transfer principle is implemented for laborers protection who are working for outsourcing business, but following the issuance of the Job Creation Law product, the law protection for outsourced employees contained in Article 81st point 20, that says the protection of wages, welfare, and legal protection are the obligations for companies as long as the work object still exists. The existing protection is not able to overcome the losses that will be experienced by outsourcing workers and the effects that will be experienced by all Indonesian workers. The absence of boundaries results in constitutional rights of workers violation like the absence of guarantees of eligibility for benefits such as pensions, severance pay, allowances, and bonuses every month. This flawed point will be utilized by employers to hand over all work in their business to a company that provides transfer services.

In this case, it can be recommended to apply for a judicial review to the Constitutional Court as an appropriate and democratic legal step and in line with Article 9th point (1) of Law Number 12 the Year 2011 concerning the establishment of legislation which explains that "if a law or regulation is allegedly opposed to the 1945 Constitution of the Republic of Indonesia, the review is necessarily conducted by the Constitutional Court. Judicial review can be submitted with material review, to examine several articles that either directly or indirectly violate the constitutional rights of workers, especially outsourcing workers who receive minimal protection and trade unions as regulated in the 1945 Constitution.

\section{ACKNOWLEDGMENTS}

The author wishes to thank the Faculty of Social Science and Law, Universitas Negeri Surabaya, for providing the need to publish this Article

\section{REFERENCES}

[1] T. S. R. Kranenburg, Ilmu Negara Umum (Law State Science), Jakarta, Pradnya Paramita, 1989, p. 16.

[2] G. Poggi, The Development of the Modern State "Sociological Introduction", California, Stanford University Press, 1992, p. 126.

[3] S. Damanik, Outsourcing \& Perjanjian Kerja, Jakarta: DSS Publishing, 2006.

[4] M. G. A. Suyoko Suyoko, "Tinjauan yuridis terhadap sistem alih daya (outsourcing) pada pekerja di Indonesia," Jurnal Cakrawala Hukum, vol. 12(1), pp. 99- 109, 2020.

[5] N. Alfiyani, "Perbandingan Regulasi
Ketenagakerjaan Dalam Undang-Undang Ketengakerjaan Dan Undang- Undang Cipta Kerja," An-Nizam: Jurnal Hukum dan Kemasyarakatan, vol. 14(2), pp. 121-139, 2020.

[6] A. S. H. Husni, "Pelaksanaan Hubungan Kerja Dengan Sistem outsourcing, Setelah Putusan Mahkamah Konstitusi No.27/ PUU-IX/2011," Jurnal Masalah- Masalah Hukum, p. Volume 45 No. 3, 2014.

[7] A. Darmawan, "Pengaturan Hukum Terhadap Pekerja Outsourcing," Varia Hukum, vol. 3(2), pp. 12-25, 2021.

[8] R. M. Johnny Lieke, "Legal Protection of Labour Outsourcing in Indonesia in the Perspective Human Rights," Journal of Law, Policy and Globalization, vol. 60, pp. 39-47, 2017.

[9] S. M. Dr. Khairani, Kepastian Hukum Hak Pekerja Outsourcing, Jakarta: RAJAGRAFINDO PERSADA, 2016.

[10] A. H. Hadry Harahap, "Analysis of The Importance of Omnibus Law "Cipta Karya" in Indonesia," International Journal of Scientific Research and Management, vol. 8(08), pp. 236-250, 2020.

[11] S. R. Soeroso, Pengantar Ilmu Hukum, Jakarta: Sinar Grafika, 2009. 